\title{
Stress conditions in soybean areas based on measurements of soil-plant-atmosphere system and UAV images ${ }^{1}$
}

\author{
Marley Lamounier Machado², Maria Lélia Rodriguez Simão², \\ Fúlvio Rodriguez Simão ${ }^{2}$, Rômulo César Soares Alexandrino ${ }^{3}$
}

\section{ABSTRACT}

The identification of stress conditions in soybean crops is, in most cases, inaccurate, since they may not be noticeable to their full extent if only walking observations are carried out in the crop fields. This study aimed to identify the stress conditions in soybean crops, in three growing environments, in the Minas Gerais state, Brazil, using image processing techniques obtained by UAV, leaf and soil sensors, and climate data. The surveys encompassed two growth stages [beginning of blooming (R1) and beginning of seed enlargement (R5)] and consisted on UAV flights; mapping of chlorophyll content, soil moisture and soil $\mathrm{pH}$; in addition to climate data. The HSV and yCbCr color models applied to RGB images showed the best Kappa accuracy index for the identification of crop features. The soil $\mathrm{pH}$ and moisture (water availability), solar radiation and temperature affected the crop growth and development in the study regions, in the R1 and R5 reproductive stages. However, the soil $\mathrm{pH}$ had less influence than the climatic variables. The R5 stage showed a greater vulnerability to stress caused by soil moisture and temperature.

KEYWORDS: Precision agriculture, remote sensing, unmanned aerial vehicle, water stress.

\section{INTRODUCTION}

Brazil is the second largest soybean producer in the world, with an area of 35.657 million hectares and yield of 123.664 million tons, in the $2018 / 2019$ harvest, accounting for $31.7 \%$ of the global production (Embrapa Soja 2019), being the Minas Gerais state the seventh largest producer in the country (IBGE 2018).

Such expansion of soybean crops may also lead to increased limiting factors related to climate, soil and biological agents. Climate is the

\section{RESUMO}

Condições de estresse em áreas de soja a partir de medidas do sistema solo-planta-atmosfera e imagens de VANT

Aidentificação das condições de estresse em lavouras de soja é, na maioria das vezes, imprecisa, e pode não ser perceptível em toda a sua extensão, quando a observação é feita por caminhamento no local. Objetivou-se identificar as condições de estresse em lavouras de soja, em três ambientes de cultivo, no estado de Minas Gerais, utilizando-se técnicas de processamento de imagens obtidas por VANT, sensor foliar e de solo, e dados climáticos. Os levantamentos foram realizados em duas fases [início do florescimento (R1) e início do enchimento das sementes (R5)] e consistiram de voos com VANT; mapeamento da clorofila, umidade e pH do solo; além de dados climáticos. Os modelos de cores HSV e yCbCr aplicados a imagens RGB apresentaram os melhores índices de acurácia Kappa para a identificação de feições da lavoura. $\mathrm{O}$ pH e a umidade do solo (disponibilidade de água), radiação solar e temperatura afetaram o crescimento e desenvolvimento da lavoura nas regiões de estudo, nos estádios reprodutivos $\mathrm{R} 1$ e R5. Porém, o pH do solo teve menor influência que as variáveis climáticas. O estádio R5 demonstrou maior vulnerabilidade a estresse por umidade do solo e temperatura.

PALAVRAS-CHAVE: Agricultura de precisão, sensoriamento remoto, veículo aéreo não tripulado, estresse hídrico.

factor most difficult to control, because it exerts a greater limiting action over plant development. Soil chemical characteristics, however, influence the crop physiology. On the other hand, plant diseases are also among the main factors that limit the achievement of high soybean yields (Embrapa Soja 2011).

Plant responses to a given stress are variable, depending on its duration, in relation to the phenological cycle. It is worth noting that a stress event may affect plants differently according to their growth stage. In addition, the crop regions under stress conditions may not be thoroughly noticeable

\footnotetext{
${ }^{1}$ Received: Dec. 17, 2019. Accepted: May 26, 2020. Published: Aug. 31, 2020. DOI: 10.1590/1983-40632020v5061785.

${ }^{2}$ Empresa de Pesquisa Agropecuária de Minas Gerais, Belo Horizonte, MG, Brasil. E-mail/ORCID: marley@epamig.br/ 0000-0002-4592-2418, lelia.epamig@gmail.com/0000-0002-5571-9157, fulvio@epamig.br/0000-0003-0682-4812.

${ }^{3}$ Fundação Estadual do Meio Ambiente, Belo Horizonte, MG, Brasil. 
if only walking observations are performed. One solution is to use crop images obtained by aerial devices, which may be used as mechanisms to quickly and accurately identify areas under stress conditions. In this sense, unmanned aerial vehicles (UAV), fitted with specific sensors and peripherals, arise as a low-cost technological solution for highperformance mapping, as they are portable and can easily take off, land, fly at low altitudes and carry multispectral cameras that provide mapping with a better spatial and spectral resolution (Hunt Junior \& Daughtry 2018).

Soybean stress during the reproductive phases can decrease the number of flowers, pods and branches, resulting in a lower seed production. This may be related to soil evaporation and plant transpiration, and involves factors such as net radiation, temperature, relative humidity, wind speed, soil available water, etc. Under stress conditions caused by temperature increase, an evaporative demand increase occurs with a decrease in soil moisture, as well as an increase in the photorespiration rate. Thus, the occurrence of hot flushes of $6{ }^{\circ} \mathrm{C}$ above the monthly average for three days of stress, in the transition stage of fertile flower to developing pod, may reduce yield, due to the high temperature sensitivity (Siebers et al. 2015). In case of low humidity in the soil (such as 11-12\% of the volumetric moisture) during the reproductive phases, a significant yield loss may occur, reaching $64 \%$ for seed weight, and $15 \%$ of soil volumetric humidity may be considered a limit stress for soil water stress under specific conditions (Wijewardana et al. 2018). On the other hand, crops with a shorter absorption time for solar radiation may experience a yield loss of $0.6 \%$ day $^{-1}$ or $2 \mathrm{~kg} \mathrm{ha}^{-1}$ at each $\mathrm{Mj} \mathrm{m}^{-2}$ (Faé et al. 2020).

In parallel, other devices for agricultural use can be resorted to, in order to achieve a reliable automated detection of different forms of stress, which can be an alternative to traditional monitoring systems. In this vein, sensors have been used to monitor weather and soil conditions, crop health, agricultural product quality and irrigation planning (Jawad et al. 2017, Goldstein et al. 2018).

Across the Minas Gerais state, the Triângulo Mineiro, Alto Paranaíba and Noroeste de Minas regions account for $85 \%$ of the state soybean yield (IBGE 2018). However, the possibility of increasing even more the yields in these regions is sought by the analysis of factors that spatially and temporally interact with the crop, as a way to improve the diagnosis and rational use of agricultural inputs and water, and to improve agricultural management.

Thus, this study aimed to identify stress conditions in soybean crops, in three cultivation environments, using images obtained by UAV processing techniques, leaf and soil sensor, and climatic data, in areas representative of the main producing regions of the Minas Gerais state.

\section{MATERIAL AND METHODS}

Surveys were carried out on soybean crops in the municipalities of Conceição das Alagoas, Rio Paranaíba and Bonfinópolis de Minas, located in the Triângulo Mineiro, Alto Paranaíba and Noroeste de Minas regions, respectively, in the Minas Gerais state, Brazil, with each crop covering an estimated area of 50 ha (Figure 1).

The soils of the study areas are clayey RedYellow Oxisol (Bonfinópolis de Minas and Rio Paranaíba) and clayey Red Oxisol (Conceição das Alagoas). The climate, according to the Köppen classification, is tropical dry winter $(\mathrm{Cwb})$ in Rio Paranaíba, and tropical Savannah (Aw) in Conceição das Alagoas and Bonfinópolis de Minas.

The surveys consisted of UAV flights; mapping of chlorophyll content, soil moisture and soil $\mathrm{pH}$; as well as climate data (air temperature and rainfall) obtained from weather stations located at the crop fields (automatic stations) and/or in neighboring municipalities (conventional stations).

The survey started in Bonfinópolis de Minas (16 $21^{\prime} 51^{\prime \prime}$ S and 46 $\left.23^{\circ} 47^{\prime \prime} \mathrm{W}\right)$, using the Monsoy

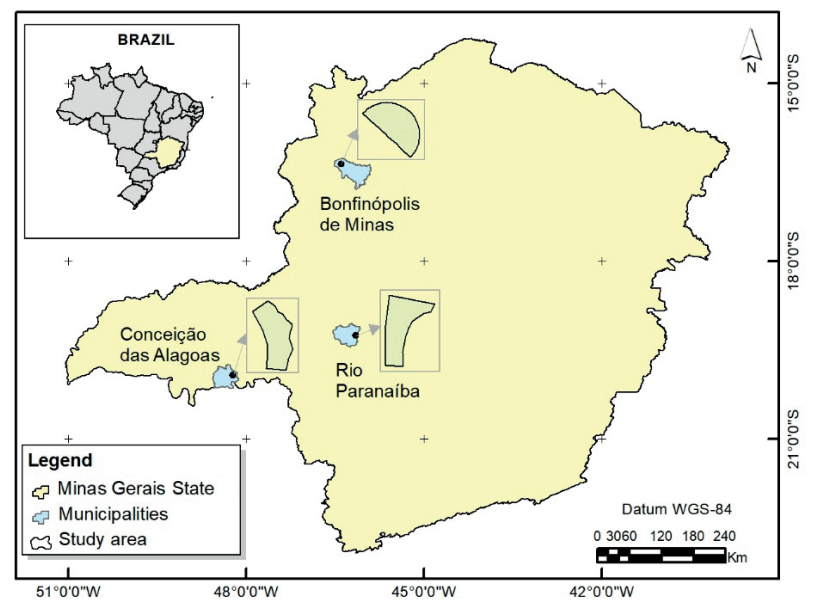

Figure 1. Location map of the study areas. 
6210 cultivar, in a 110-day cycle, at a density of 17 seeds $\mathrm{m}^{-1}$ and spacing of $0.5 \mathrm{~m}$, in an irrigated area, planted on November 02, 2016. In parallel, a survey was initiated in Conceição das Alagoas (19 ${ }^{\circ} 55^{\prime} 33^{\prime \prime}$ S and $\left.48^{\circ} 13^{\prime} 35^{\prime \prime} \mathrm{W}\right)$, using the BRS 7980 cultivar, in a 125-day cycle, at a density of 15 seeds $\mathrm{m}^{-1}$ and spacing of $0.5 \mathrm{~m}$, in a rainfed area, planted on October 20, 2016. The third survey was carried out in Rio Paranaíba (19 $15^{\prime} 22^{\prime \prime}$ S and $\left.46^{\circ} 09^{\prime} 00^{\prime \prime} \mathrm{W}\right)$, where the Monsoy 7739 cultivar was used, in a 130-day cycle, at a density of 13 seeds $\mathrm{m}^{-1}$ and spacing of $0.5 \mathrm{~m}$, in a rainfed area, planted on November 25, 2017. The surveys encompassed two growth stages: beginning of blooming (R1) and beginning of seed enlargement (R5). Fertilization and liming were carried out annually in the fields.

The limit of each area was mapped using a geodetic GPS modulated onto the L1 carrier, whose accuracy was less than $0.015 \mathrm{~m}$. Within the limit, a two-dimensional grid with $100 \mathrm{~m}$ equidistance was established, totaling 50 sampling points (Cogalton 1991) installed in the crop area for the identification of moisture, $\mathrm{pH}$ and chlorophyll measurement sites.

One UAV (model 3DR SOLO), fitted with two cameras (model MAPIR SURVEY 1-12 MegaPixel), was used to get images, one in the spectral range of the visible $(360-680 \mathrm{~nm})$ and the other in the spectral range of the infrared $(790-830 \mathrm{~nm})$. Images were taken at a resolution of $4 \mathrm{~cm}$ pixel $^{-1}$, at an altitude of $100 \mathrm{~m}$, between 11 a.m. and 1 p.m. (local Brasília time, to minimize the influence on solar geometry - zenith and azimuth). The flight speed was approximately $7 \mathrm{~m} \mathrm{~s}^{-1}$ and the overlapping (longitudinal and transversal) between images was $70 \%$. The flights were performed at a wind speed of less than $5 \mathrm{~m} \mathrm{~s}^{-1}$.

The soil $\mathrm{pH}$ was measured using a PHD-3000 meter (Instruterm Instrumentos de Medição Ltda.), at a depth of $14 \mathrm{~cm}$, operating temperature between $5{ }^{\circ} \mathrm{C}$ and $45^{\circ} \mathrm{C}$, within the range between 0 and $14 \mathrm{pH}$, at a resolution of $0.1 \mathrm{pH}$ and precision of $0.02 \mathrm{pH}$. The soil moisture was measured, in terms of volumetric water content, using a Hidrofarm HMF2010 meter (Falker Automação Agrícola Ltda.), with a $20 \mathrm{~cm}-$ rod sensor, within the range from 0 to $60 \%$, at a resolution of $0.1 \%$ and accuracy of $\pm 3 \%$. The soil $\mathrm{pH}$ and moisture values for each sampling point in the grid were drawn on an average of three measurements spaced $1.5 \mathrm{~m}$ apart. All measurements were taken in walking observations on the day before or after the
UAV flight, and under similar weather conditions among the observation days, in order to minimize data errors regarding plant physiological changes.

The leaf chlorophyll content was measured using a Clorofilog meter (Falker Automação Agrícola Ltda.), whose measurement scale ranges from 0 to 100 , at a 0.1 resolution, and a leaf measurement area of $50.3 \mathrm{~mm}^{2}$. The chlorophyll content value was expressed as per the Falker Chlorophyll Index (FCI), which corresponds to the measurement of the amount of radiation transmitted through leaves.

The field data contained in the sampling grid were spatially analyzed by geostatistics, in order to determine the degree of spatial dependence between the samples, by means of a semivariogram model (Equation 1):

$$
\mathrm{y}(\mathrm{h})=1 / 2 \mathrm{n} \sum\{\mathrm{x}(\mathrm{i}+\mathrm{h})-\mathrm{x}(\mathrm{i})\}^{2}
$$

where: $\mathrm{i}$ is the geographical position; $\mathrm{h}$ the distance interval; and $\mathrm{y}(\mathrm{h})$ the semivariogram. Under this model, data are generated and used to adjust another mathematical model that allows the data interpolation in the sampling grid, in order to map the area. All interpolations were done by ordinary kriging.

Six topographic targets were placed at the vertices of the area where the respective coordinates were subsequently obtained using the Geodetic GPS. These targets were imaged simultaneously with the crop, thus allowing for image georeferencing.

Reference plates with known reflectance values were also placed in the scene to correct lighting effects in the obtained images. The plates, measuring $0.90 \mathrm{~m} \times 0.90 \mathrm{~m}$, were painted with antireflective paint in four different shades (white, light gray, medium gray and dark gray). The reflectance values of the reference plates were obtained using a HandHeld-2 spectroradiometer, at wavelengths between $325 \mathrm{~nm}$ and $1,075 \mathrm{~nm}$ and resolution of $1 \mathrm{~nm}$. The mean reflectance values of the plates corresponding to the wavelengths of each plate, combined with the respective values measured in the image, were used to transform the original pixel values of the images into reflectance values (Equation 2):

$$
\hat{Y}=\hat{\beta}_{0}+\hat{\beta}_{1} P
$$

where: $\hat{Y}$ is the estimated reflectance value for a given band; $\hat{\beta}_{0}$ the regression constant; $\hat{\beta}_{1}$ the regression coefficient; and $\mathrm{P}$ the pixel value in the original image for a given band. 
Climate crop information in the field of the survey period for precipitation and solar radiation were obtained from automatic weather stations (A) belonging to the Instituto Nacional de Meteorologia - Inmet and Cooperativa Agropecuária do Alto Paranaíba - Coopadap (Table 1).

Mean temperatures were estimated for the sampling points using multivariate linear models based on historical data series from conventional weather stations of Minas Gerais and bordering states, from 1980 to 2013, established in 10-day intervals (Minas Gerais 2017) (Equation 3):

$\mathrm{Tm}=\beta_{0}+\beta_{1}$ latitude $-\beta_{2}$ longitude $-\beta_{3}$ altitude $+\varepsilon$

where: latitude and longitude: absolute values in decimal degree; altitude: values expressed in meters; $\beta_{0}$ : regression constant; $\beta_{1}, \beta_{2}$ and $\beta_{3}$ : partial regression coefficients; and $\varepsilon$ : error. The parameters of this equation were based on the ten-day period that comprised the stages R1 through R5, and on the geographical coordinates of the sampling grid for each crop (Table 2).

The variable $\varepsilon$ in Equation 3 was used as the difference between the estimated value and the value registered in the weather station installed in the field.

The images originated from the UAV were stitched using the Microsoft ICE (Microsoft Corporation) and Panavue (Panavue Inc.) softwares. Subsequently, the stitched images were georeferenced using the Quantum GIS 2.14 geographic information system. Then, lighting effects were corrected, and the original RGB color model was transformed into HSV scale (hue, saturation, value), Lab color space (L: luminance; a-b: chrominance values) and $\mathrm{yCbCr}$ color model (y: luminance, $\mathrm{Cb}$ : difference between the blue component and a reference value; $\mathrm{Cr}$ : difference between the red component and a reference value).

Land use classes were identified in the crops (healthy soybean, soybean under stress, exposed soil, shade and invasive plant) using a supervised classification method by quadratic discriminant analysis (Tibi et al. 2018) (Equation 4):

$\mathrm{D}_{\mathrm{i}}(\mathrm{X})=\ln \left(\mathrm{p}\left(\mathrm{W}_{\mathrm{i}}\right)\right)-1 / 2 \ln \left|\mathrm{C}_{\mathrm{i}}\right|-1 / 2\left[\left(\mathrm{X}-\mathrm{m}_{\mathrm{i}}\right)^{\mathrm{T}} \cdot \mathrm{C}_{\mathrm{i}}^{-1} \cdot\left(\mathrm{X}-\mathrm{m}_{\mathrm{i}}\right)\right]$

where: $\mathrm{D}_{\mathrm{i}}(\mathrm{X})$ : class ' $\mathrm{i}$ ' discriminant function of the random vector $\mathrm{X} ; \mathrm{C}_{\mathrm{i}}$ : covariance matrix of the class 'i'; $\mathrm{X}$ : random vector of characteristics; $\mathrm{m}_{\mathrm{i}}$ : mean vector of the class ' $\mathrm{i}$ '; $\mathrm{p}\left(\mathrm{W}_{\mathrm{i}}\right)$ : probability of class ' $\mathrm{i}$ ' occurrence.

For the supervised classification, 50 samples of each class of land use were identified based on visual identification, during the walking in the farm (field truth), $70 \%$ of which were used for training and $30 \%$ for validation (Machado et al. 2015, Ji' an et al. 2019). The validation samples were used to measure the classification performance by means of the Kappa index (Cohen 1960) (Equation 5):

$$
\hat{K}=\frac{n \sum_{i=1}^{c} x_{i}-\sum_{i=1}^{c} x_{i \oplus} x_{\oplus i}}{n^{2}-\sum_{i=1}^{c} x_{i \oplus} x_{\oplus i}}
$$

Table 1. Study areas in the Minas Gerais state, Brazil, and their distances from the weather stations.

\begin{tabular}{llrl}
\hline \multicolumn{1}{c}{ Study area } & \multicolumn{1}{c}{ Station location } & Distance $(\mathrm{km})$ & Responsible \\
\hline Bonfinópolis de Minas & Unaí & 31.4 & Inmet \\
Conceição das Alagoas & Conceição das Alagoas & 9.9 & Inmet \\
Rio Paranaíba & São Gotardo & 12.6 & Coopadap \\
\hline
\end{tabular}

Table 2. Regression coefficients model for estimating temperatures during the 10-day period.

\begin{tabular}{|c|c|c|c|c|c|c|}
\hline \multirow{2}{*}{ 10-day period } & \multirow{2}{*}{ Location-stage } & \multicolumn{4}{|c|}{ Partial regression coefficient } & \multirow{2}{*}{$\mathrm{R}^{2}$} \\
\hline & & $\beta 0$ & $\beta 1$ & $\beta 2$ & $\beta 3$ & \\
\hline 3 & Conceição das Alagoas - R5 & 26.281 & 0.175 & 0.107 & 0.006 & $94.2^{*}$ \\
\hline 7 & Rio Paranaíba - R5 & 25.946 & 0.198 & 0.127 & 0.006 & $93.6^{*}$ \\
\hline 29 & Bonfinópolis de Minas - R1 & 19.128 & 0.602 & 0.434 & 0.006 & $89.2^{*}$ \\
\hline 31 & Bonfinópolis de Minas - R5 & 20.265 & 0.416 & 0.327 & 0.006 & $91.9^{*}$ \\
\hline 32 & Rio Paranaíba - R1 & 21.349 & 0.379 & 0.289 & 0.006 & $93.5^{*}$ \\
\hline 35 & Conceição das Alagoas - R1 & 23.217 & 0.192 & 0.173 & 0.006 & $95.6^{*}$ \\
\hline
\end{tabular}

* Highly significant. 
where: $x_{i i}$ : element of the confusion matrix in row $\mathrm{i}$ and column $\mathrm{i}$ (diagonal) of the error matrix; $\mathrm{x}_{\oplus \mathrm{i}}$ : sum of line $\mathrm{i}$; $\mathrm{x}_{\mathrm{i} \oplus}$ : sum of column $\mathrm{i}$; $\mathrm{n}$ : total number of samples; and c: total number of classes.

In order to define the best classification, the Kappa indices were compared with each other using the $\mathrm{Z}$ test, at a 0.05 significance level (Congalton \& Mead 1983).

Multivariate principal component analysis (PCA) techniques were used to reduce redundant information and to identify the variables that most contribute to crop stress. The analysis used the independent variables of soil moisture, soil $\mathrm{pH}$ and estimated mean air temperature.

\section{RESULTS AND DISCUSSION}

Table 3 shows the best values of the Kappa index and the color model into which the RGB images were transformed for the supervised classification of the UAV images at the R1 and R5 stages, in each studied municipality.

The classification of such images is shown in Table 4, where the classes for healthy soybean, soybean under stress, exposed soil, shade and invasive plant were considered. The "healthy soybean" rate in Bonfinópolis de Minas is much lower than those observed for Conceição das Alagoas and Rio Paranaíba (R1 and R5 stages). Therefore, Bonfinópolis de Minas showed the highest rate of "soybean under stress", in the R5 stage, corresponding to $45.56 \%$ of the area. This information demonstrates the poorest vegetative conditions for soybean crop in this municipality.

Table 5 describes the variability of the 50 sample points for chlorophyll, $\mathrm{pH}$ and soil moisture. In the R1 stage, the highest average value was found in Rio Paranaíba, and, in the R5 stage, in Conceição das Alagoas.

Figure 2 shows soil moisture maps of Bonfinópolis de Minas, Conceição das Alagoas and Rio Paranaíba (R1 and R5 stages), in addition to contour lines that indicate the relationship between the moisture levels and the topography of the sites.

Water contents lower than $20 \%$ were considered susceptible to permanent wilting point (PWP) (FAA 2008) to predominantly clay soil texture (Figure 2). Accordingly, Conceição das Alagoas was the place where the area had minor risks of PWP in R1. An inverse situation was observed in Bonfinópolis de Minas, where the whole area in R1 migrated to PWP conditions in R5. Gava et al. (2015) mention a yield loss of $9.1 \%$, when there is water stress in the soil at R1, and $37.9 \%$ at R5. In Rio Paranaíba, most of the area under $\mathrm{PWP}$ in R1 was no longer as such in R5. Conceição das Alagoas was the place with the greatest topographical elevation difference, indicating that least moist areas tend to concentrate in the lower regions of the crop fields.

Table 3. Best Kappa index values and transformed image color model for the supervised classification.

\begin{tabular}{|c|c|c|c|c|}
\hline \multirow{2}{*}{ Municipality } & \multicolumn{2}{|c|}{ R1 stage } & \multicolumn{2}{|c|}{ R5 stage } \\
\hline & Color model* & Kappa & Color model & Kappa \\
\hline Bonfinópolis de Minas & HSV & 1.00 & HSV & 0.92 \\
\hline Conceição das Alagoas & HSV & 0.87 & HSV & 0.79 \\
\hline Rio Paranaíba & $\mathrm{YCbCr}$ & 0.91 & $\mathrm{yCbCr}$ & 0.93 \\
\hline
\end{tabular}

* HSV scale (hue, saturation, value) and yCbCr color model (y: luminance, $\mathrm{Cb}$ : difference between the blue component and a reference value; Cr: difference between the red component and a reference value).

Table 4. Quantification of rates by area, based on the images with the best Kappa index.

\begin{tabular}{|c|c|c|c|c|c|c|}
\hline \multirow{3}{*}{ Classes } & \multicolumn{6}{|c|}{ Rates by area } \\
\hline & \multicolumn{2}{|c|}{ Bonfinópolis de Minas } & \multicolumn{2}{|c|}{ Conceição das Alagoas } & \multicolumn{2}{|c|}{ Rio Paranaíba } \\
\hline & $\mathrm{R} 1$ & $\mathrm{R} 5$ & $\mathrm{R} 1$ & $\mathrm{R} 5$ & $\mathrm{R} 1$ & $\mathrm{R} 5$ \\
\hline Healthy soybean & 43.36 & 25.53 & 84.08 & 82.40 & 79.15 & 91.47 \\
\hline Soybean under stress & - & 45.56 & - & 13.36 & - & - \\
\hline Exposed soil & 16.10 & 8.05 & 1.49 & 1.19 & 11.00 & 1.27 \\
\hline Shade & 34.32 & 18.50 & 3.35 & 0.41 & 3.22 & 3.22 \\
\hline Invasive plant & 6.22 & 2.36 & 11.08 & 2.65 & 6.64 & 4.04 \\
\hline
\end{tabular}


Table 5. Descriptive statistics of the sampling points [average, standard deviations (SD) and coefficient of variation (CV)] of the variables soil moisture $(\theta \%)$, soil $\mathrm{pH}$ (admissible), temperature $\left({ }^{\circ} \mathrm{C}\right)$ and chlorophyll (admissible), to the studied municipalities and phenological stages.

\begin{tabular}{|c|c|c|c|c|c|c|c|}
\hline \multirow{2}{*}{ Variables } & \multirow{2}{*}{ Statistic } & \multicolumn{6}{|c|}{ Municipality/Stages } \\
\hline & & BM-R1* & BM-R5 & CA-R1 & CA-R5 & RP-R1 & RP-R5 \\
\hline \multirow{3}{*}{$\theta \%$} & Average & 18.40 & 6.04 & 22.52 & 31.63 & 15.01 & 28.93 \\
\hline & SD & 2.91 & 2.44 & 4.20 & 4.36 & 5.40 & 2.33 \\
\hline & $\mathrm{CV}$ & 15.80 & 40.34 & 18.66 & 13.80 & 35.95 & 8.06 \\
\hline \multirow{3}{*}{ Soil pH } & Average & 6.10 & 6.12 & 5.49 & 5.50 & 6.02 & 5.78 \\
\hline & SD & 0.32 & 0.16 & 0.30 & 0.29 & 0.22 & 0.16 \\
\hline & $\mathrm{CV}$ & 5.22 & 2.64 & 5.43 & 5.28 & 3.63 & 2.71 \\
\hline \multirow{3}{*}{ Temperature } & Average & 21.53 & 23.01 & 23.71 & 24.81 & 21.69 & 21.67 \\
\hline & SD & 0.02 & 0.02 & 0.06 & 0.05 & 0.02 & 0.02 \\
\hline & $\mathrm{CV}$ & 0.08 & 0.07 & 0.24 & 0.21 & 0.07 & 0.07 \\
\hline \multirow{3}{*}{ Chlorophyll } & Average & 36.98 & 40.23 & 39.60 & 41.97 & 34.10 & 39.94 \\
\hline & SD & 1.78 & 2.23 & 2.08 & 2.24 & 2.83 & 3.18 \\
\hline & $\mathrm{CV}$ & 4.82 & 5.53 & 5.25 & 5.33 & 8.30 & 7.97 \\
\hline
\end{tabular}

* BM: Bonfinópolis de Minas; CA: Conceição das Alagoas; RP: Rio Paranaíba; R1: beginning of blooming; R5: beginning of seed enlargement.
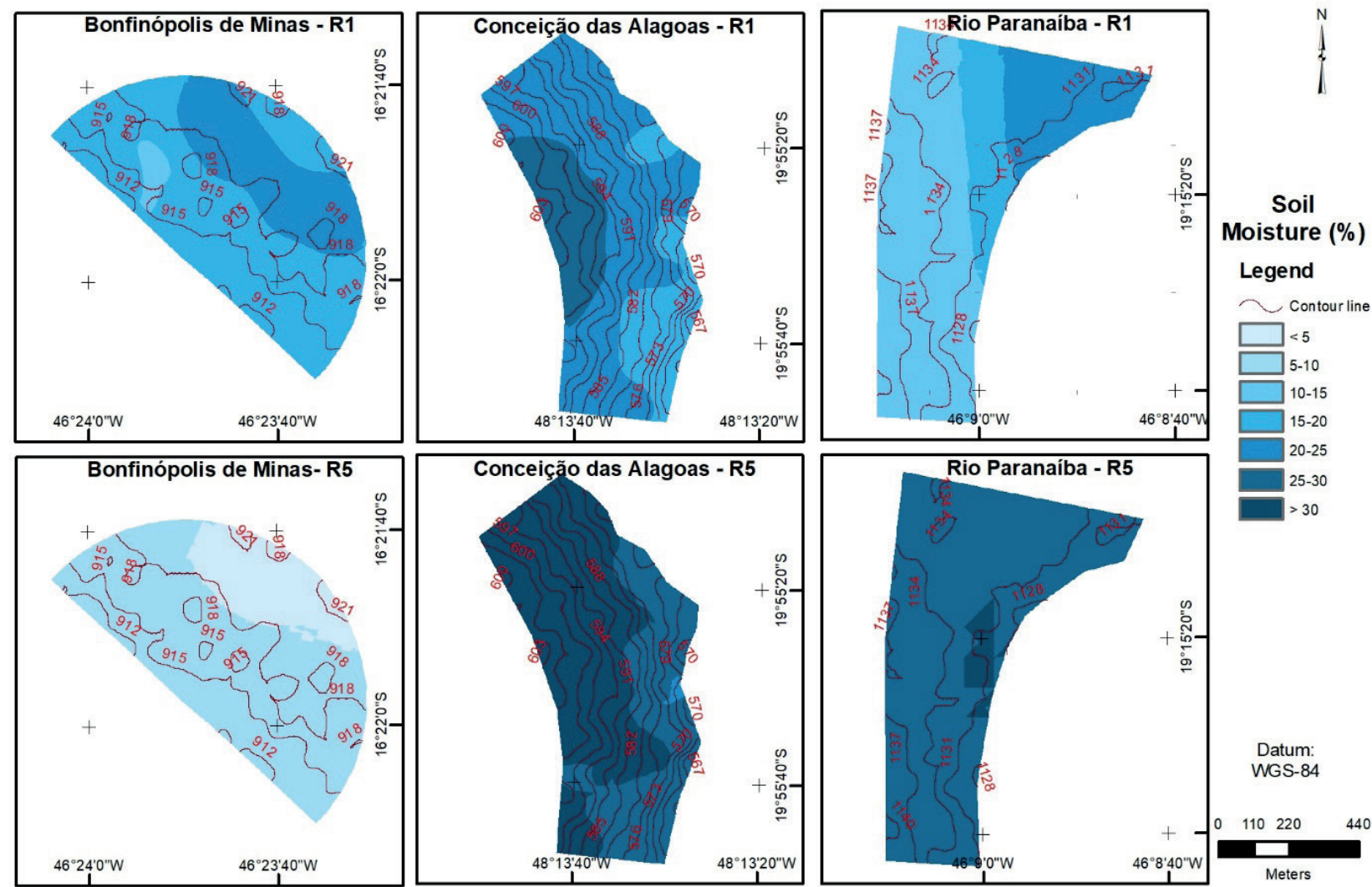

Figure 2. Soil moisture in the crops under study (R1 and R5 stages) and contour lines.

From the data obtained in Red-Yellow Argisol with clayey texture by electronic volumetric humidity sensor, Ruviaro et al. (2011) identified values of $35.7 \%, 16.90 \%$ and $26.3 \%$, respectively for field capacity, permanent wilting point and critical humidity, which provide the maximum and water that could be transferred to the atmosphere by evapotranspiration by soybean crops without causing yield losses. The condition of moisture stress or lack of adequate soil moisture during reproductive stages 
influences the grain yield, with water stress values below $-0.5 \mathrm{MPa}$ promoting a severe reduction in the weight and quantity of seeds, when compared to water stress between -0.05 and $-0.1 \mathrm{MPa}$ (Krishnan et al. 2014). Using electronic volumetric moisture meters in a sandy loam texture soil, Wijewardana et al. (2018) found that a decrease in humidity from $15 \%$ (reference limit value) to $11 \%$, in reproductive stages, can decrease by $64 \%$ the seed weight and $21 \%$ the harvest index (weight of dry seeds by total weight). Thus, a situation of low humidity $(<20 \%)$ occurred in Bonfinópolis de Minas, mainly in reproductive stages, could compromise the crop yield.

Figure 3 shows soil $\mathrm{pH}$ maps of the study areas. For purposes of discussion, the soil $\mathrm{pH}$ range between 5.2 and 6.0 was adopted as the one that presents a more nutritionally balanced environment for soybean crops, according to technical recommendations for soil fertility and soybean nutrition (Oliveira et al. 2007).

As expressed in Figure 3, the whole area of Conceição das Alagoas (R1 and R5) and Rio Paranaíba (R5) ranged between the limit of 5.2 to 6.0 for soil $\mathrm{pH}$. Therefore, in such areas, the
$\mathrm{pH}$ would not be a restrictive factor for soybean, being within the recommended limit for the crop, according to Oliveira et al. (2007). In Conceição das Alagoas, changes were observed in areas with soil $\mathrm{pH}$ greater than and lower than 6.0 in the R5 stage, when compared to R1. In Rio Paranaíba, areas that were more basic in R1 became more acidic in R5. In Bonfinópolis de Minas, most of the area (R1 and R5) sustained the trend with a $\mathrm{pH}$ value above 6.0 , which indicates a more basic soil condition.

The mobility of basic/acid areas found in Conceição das Alagoas and Rio Paranaíba may be related to the greater amount of precipitation occurring in these locations. The accumulated rainfall from the planting date and measured in automatic stations in Conceição das Alagoas and Unaí, and São Gotardo, adjacent to Bonfinópolis de Minas and Rio Paranaíba, were $279 \mathrm{~mm}, 415 \mathrm{~mm}$ and $405 \mathrm{~mm}$, respectively, for the R1 stage; and $291 \mathrm{~mm}, 648 \mathrm{~mm}$ and $684 \mathrm{~mm}$, for the R5 stage. Thus, the expectation would be that the percolation of water in the superficial layers could contribute to a greater acidity in the soil, since the water reacts with carbon dioxide to form a weak acid. The weak acid
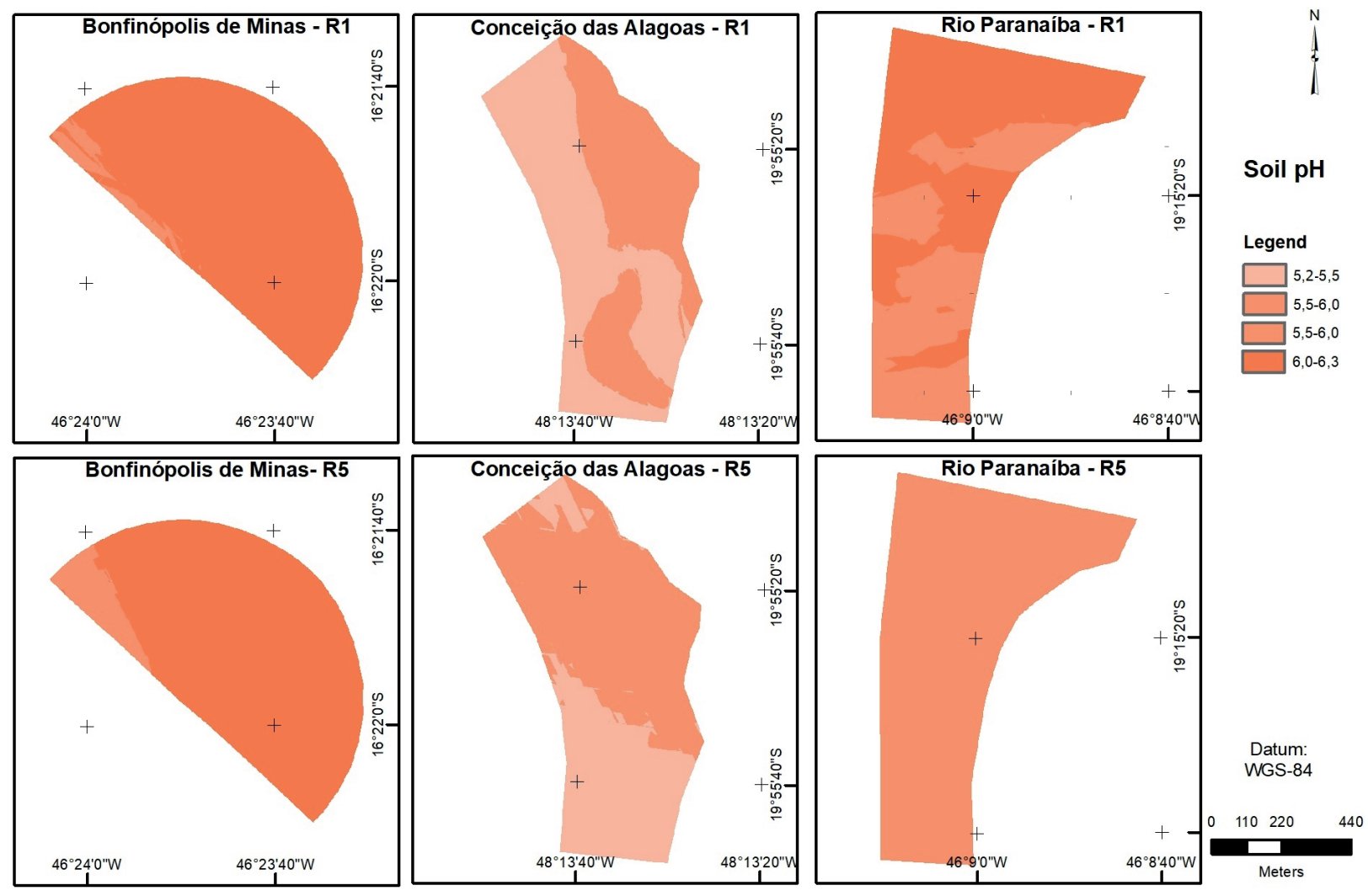

Figure 3. Soil pH for the soybean crops under study, in the R1 and R5 stages. 
ionizes, releasing hydrogen $\left(\mathrm{H}^{+}\right)$and bicarbonate $\left(\mathrm{HCO}_{3}\right)$ (Lopes et al. 1991). The released hydrogen ions replace the calcium ions retained by the soil colloids, causing the soil to become acidic (Lopes 1989).

Figure 4 shows the Falker Chlorophyll Index (FCI) maps for total chlorophyll content, considering the value of 38 as the limit for areas of low photosynthetic activity (Barbosa et al. 2018, Silva et al. 2019). Most of the areas in Bonfinópolis de Minas and Rio Paranaíba (R1 stage) presented values within this range. On the other hand, the areas with the highest total FCI were located in Conceição das Alagoas (R1 and R5 stages).

Chlorophyll levels may be related to the intensity of solar radiation present in the respective cultivation regions, as a function of the photosynthesis process. In this process, there is an action of the leaves mesophile, which is the most active photosynthetic tissue, as it contains chloroplasts, organelles rich in chlorophilic pigments specialized in light absorption (Marenco \& Lopes 2009). Therefore, it was observed that the average daily densities of the global radiation of the crop, for the R1 stage, were 1,403 $\mathrm{W} \mathrm{m}^{-2}$, $1,393 \mathrm{~W} \mathrm{~m}^{-2}$ and $1,217 \mathrm{~W} \mathrm{~m}^{-2}$, respectively for the crops in Bonfinópolis de Minas, Conceição das Alagoas and Rio Paranaíba. For the R5 stadium, they were $1,967 \mathrm{~W} \mathrm{~m}^{-2}, 1,231 \mathrm{~W} \mathrm{~m}^{-2}$ and $1,181 \mathrm{~W} \mathrm{~m}^{-2}$, respectively for the crops in Bonfinópolis de Minas, Conceição das Alagoas and Rio Paranaíba.

The average test between these values, with a $95 \%$ confidence level, indicated a statistical difference between Rio Paranaíba and the others for the R1 stadium, and between Bonfinópolis de Minas and the others for the R5 stadium. Thus, the solar radiation flow would not have influenced the chlorophyll levels of the sites in the R1 stage, since Bonfinópolis de Minas obtained the lowest FCI values and presented a solar radiation value close to that of Conceição das Alagoas. On the other hand, the increase in the solar radiation of Bonfinópolis de Minas, from the $\mathrm{R} 1$ to the R5 stage, made the daily radiation average statistically different from the others, but with FCI values still lower than for the other areas. However, Figure 2 corroborates the solar radiation information in which the area in Rio Paranaíba had a lower soil
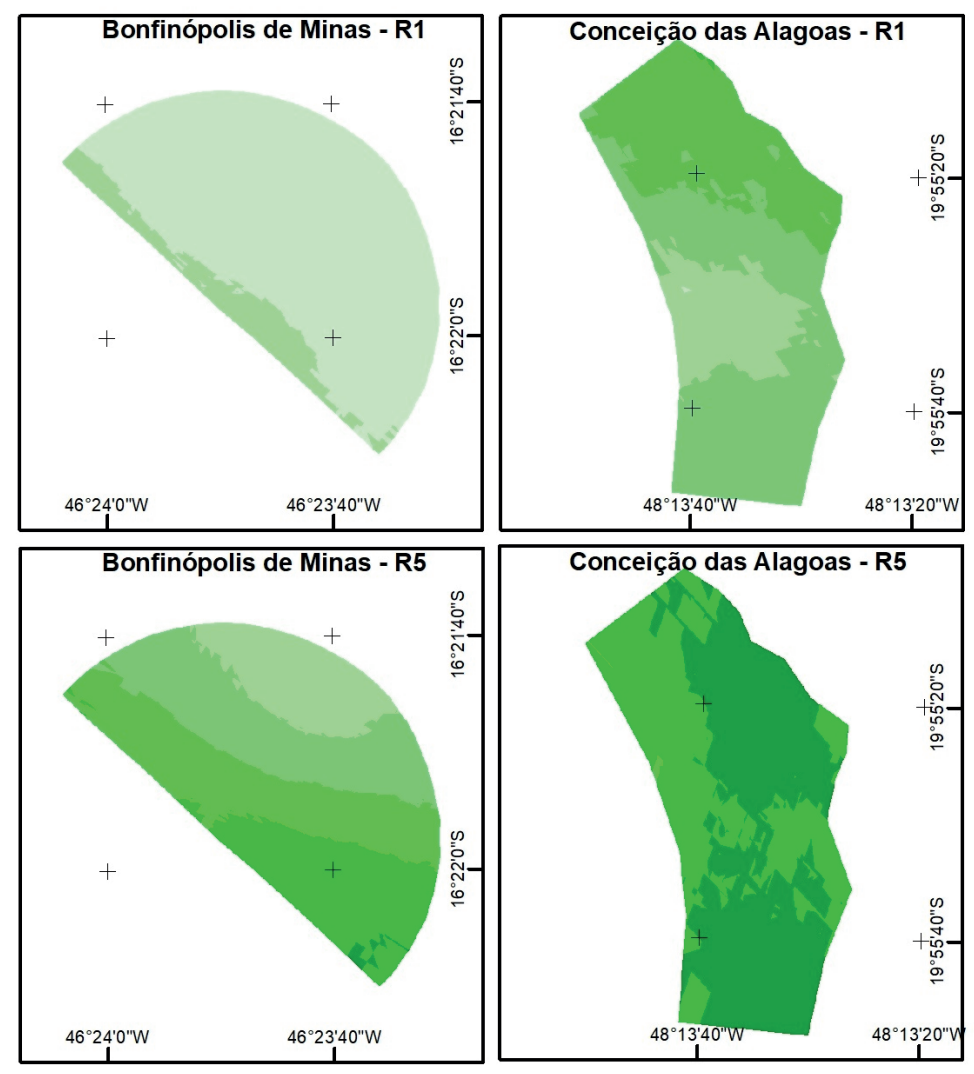

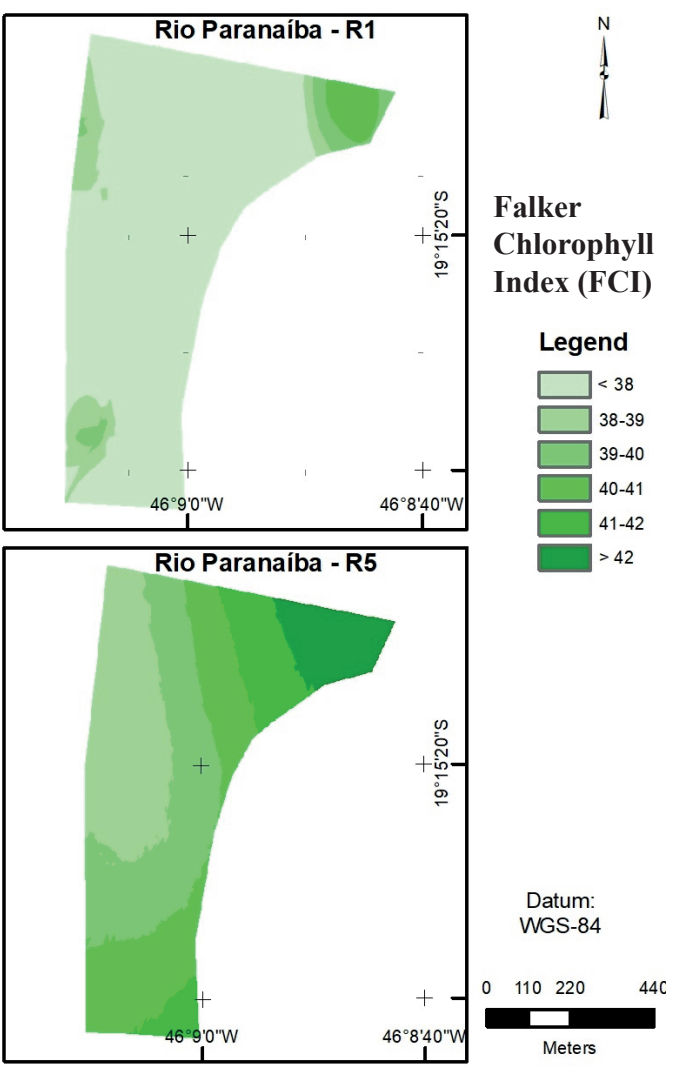

Figure 4. Falker Chlorophyll Index (FCI) for the crops under study (R1 and R5 stages). 
moisture in the R1 stage, while Bonfinópolis de Minas, in the R5 stage, showed lower values for soil moisture, in relation to the other areas, which coincided with the greatest increase in solar radiation between these stages. So, the combination of these factors (soil moisture and radiation) would possibly imply in chlorophyll in these areas. Photosynthesis, with its chlorophyll reactions, requires sufficient water transport through leaves for stomata to remain open as water transpires from the leaf (Locke \& Ort 2014). The need for water by soybean crops increases with the development of the plant until it reaches its maximum, during blooming and seed enlargement (7-8 $\mathrm{mm}$ day $\left.^{-1}\right)$ (Embrapa Soja 2011).

Table 4 shows that, in Bonfinópolis de Minas, at the R5 stage, there was a higher value for soybean areas under stress. However, Table 5 points out that the average chlorophyll value increased in R5, when compared to R1, and was close to the values of the same stage in other regions. Therefore, it suggests that chlorophyll values could, possibly, not have represented the stress in the level that occurred in the region. In the possibility of a greater influence of water stress, Chavarria et al. (2015) observed that water deficiency potentials did not influence the quantity of photosynthetic pigments of soybean plants during the studied water deficit period, when analyzing the photosynthetic activity of soybean plants under different water availabilities in the range of $-0.004 \mathrm{Mpa}$ (two days without water) to $-0.164 \mathrm{Mpa}$ (11 days without water).

Variables related to temperature, soil moisture, solar radiation and precipitation, associated with the crop planting periods, affect the process of water

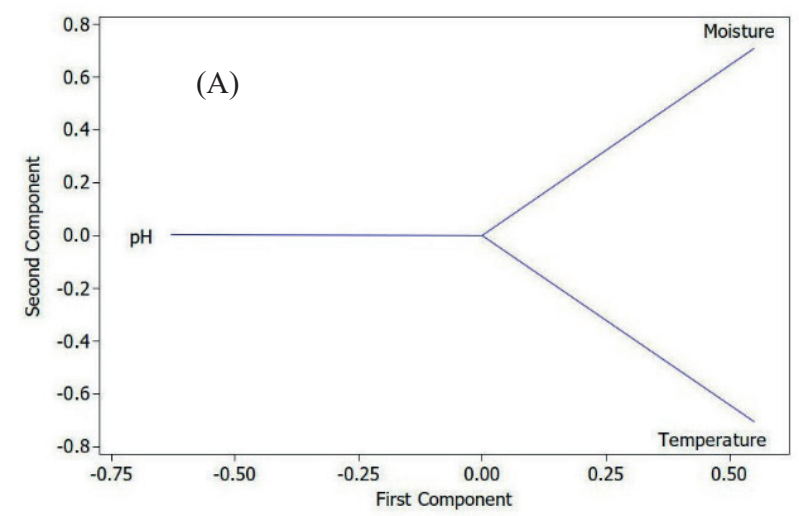

availability for the plant, due to evapotranspiration (soil evaporation and plant transpiration). In this case, there may be a water deficit when the plant transpiration is greater than the absorption of water available in the soil next to the roots. Therefore, water availability is essential for plant growth and development, specifically during the critical phenological phases (Faé et al. 2020).

The principal component analysis explained $62.2 \%$ of the information variance for the first component and $23.5 \%$ for the second component. Figure 5A shows the loading of the first component by the second.

For the first component (Figure 5A), the information variance is explained by the soil moisture and temperature in the positive direction and $\mathrm{pH}$ in the reverse direction. For the second component, the $\mathrm{pH}$ was zero, and the soil moisture and temperature explain the variance in the reverse direction, as well. Analyzing the two components together, it is observed that the climatic variables explain more the variance occurred in the field, in relation to the $\mathrm{pH}$.

Figure 5B shows the dispersion of scores of the first component by the second component. By analyzing the first component, there is a greater tendency of climatic influence for Conceição das Alagoas (R1 and R5) and Rio Paranaíba (R5). In Bonfinópolis de Minas (R1 and R5) and Rio Paranaíba (R1), there was a greater tendency to influence the soil $\mathrm{pH}$. Due to the information variance in the second component, there is a greater tendency for influence of soil moisture in Rio Paranaíba (R1 and R2) and temperature in Bonfinópolis de Minas (R5).

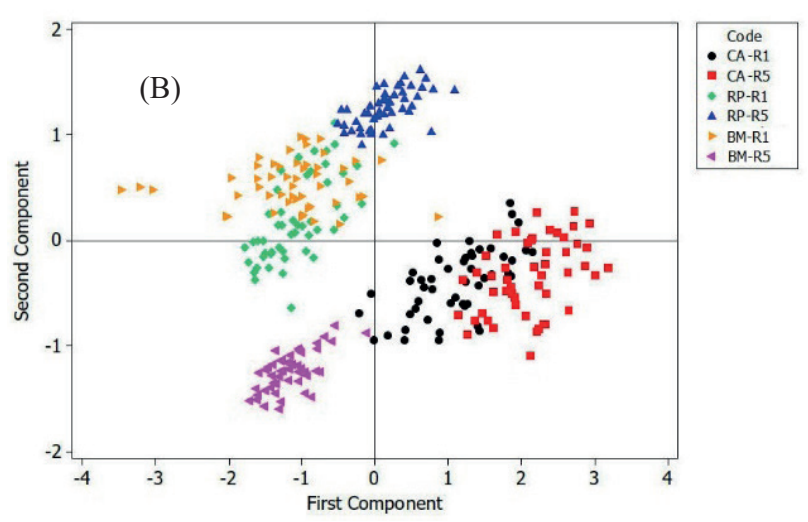

Figure 5. Principal component analysis for soil pH, air temperature and soil moisture, in the crops under study (R1 and R5 stages). A) Loading of the first component by the second component; B) sample dispersion. CA: Conceição das Alagoas; RP: Rio Paranaíba; BM: Bonfinópolis de Minas. 


\section{CONCLUSIONS}

1. Soil $\mathrm{pH}$ and moisture (water availability), solar radiation and temperature affect the crop growth and development in the study regions, in the R1 and $\mathrm{R} 5$ reproductive stages. However, the soil $\mathrm{pH}$ had less influence than the climatic variables. This suggests the need for installation or improvement of irrigation systems, and/or analysis that seek to coincide the sowing period with seasons of greater water availability for the crop, especially at the beginning of blooming (R1) and beginning of seed enlargement (R5);

2. The R5 stage showed a greater vulnerability to stress, due to soil moisture and temperature;

3. The employed methodology allowed the identification of stress conditions by integrating information from soil and climate sensors and UAV image, in a relatively short time, with a greater capacity for crop spatial analysis, when compared to traditional methods, with a not destructive diagnosis of crop appearance and saving on laboratory analysis. However, it is necessary to use more sensors (in number and types), and in a dedicated way, during the crop cycle, for a better diagnosis, considering areas of annual grain cultivation of up to 50 ha.

\section{ACKNOWLEDGMENTS}

To the Fundação de Amparo à Pesquisa do Estado de Minas Gerais (Fapemig), for financially supporting this study.

\section{REFERENCES}

BARBOSA, K. D. P.; FREITAS, L.; SILVA, P. C.; CAVALCANTE, T. J.; SILVA, A. A. F. da; SANTOS, R. F. Vegetative growth of corn and soybean plants in association with nitrogen fixing bacteria and nitrogen fertilization. Acta Iguazu, v. 7, n. 1, p. 51-59, 2018.

CHAVARRIA, G.; DURIGON, M. R.; KLEI, V. A.; KLEBER, H. Restrição fotossintética de plantas de soja sob variaçâo de disponibilidade hídrica. Ciência Rural, v. 45, n. 8, p. 1387-1393, 2015.

COHEN, J. A coefficient of agreement for nominal scales. Educational and Psychological Measurement, v. 20, n. 1, p. 37-46, 1960.

CONGALTON, R. G. A review of assessing the accuracy of classifications of remotely sensed data. Remote Sensing of Environment, v. 37, n. 1, p. 35-46, 1991.
CONGALTON, R. G.; MEAD, R. A. A quantitative method to test for consistency and correctness in photointerpretation. Photogrammetric Engineering and Remote Sensing, v. 49, n. 1, p. 69-74, 1983.

EMPRESA BRASILEIRA DE PESQUISA AGROPECUÁRIA (Embrapa Soja). Soja em números (safra 2018/19). Londrina: Embrapa Soja, 2019.

EMPRESA BRASILEIRA DE PESQUISA AGROPECUÁRIA (Embrapa Soja). Tecnologias de produção de soja: região central do Brasil 2012 e 2013. Londrina: Embrapa Soja, 2011.

FAÉ, G. S.; KEMANIAN, A. R.; ROTH, G. W.; WHITE, C.; WATSON, J. E. Soybean yield in relation to environmental and soil properties. European Journal of Agronomy, v. 118, e126070, 2020.

FALKER AUTOMAÇÃO AGRÍCOLA (FAA). Nota de aplicação - HFM 2010 - N.1: aplicações do HidroFarm. 2008. Disponível em: https://www.falker.com.br/ download.php?file_id=61. Acesso em: nov. 2019.

GAVA, R.; FRIZZONE, J. A.; SNYDER, R. L.; JOSÉ, J. V.; FRAGA JUNIOR, E. F.; PERBONI, A. Estresse hídrico em diferentes fases da cultura da soja. Revista Brasileira de Agricultura Irrigada, v. 9, n. 6, p. 349-359, 2015.

GOLDSTEIN, A.; FINK, L.; MEITIN, A.; BOHADANA S.; LUTENBERG, O.; RAVID, G. Applying machine learning on sensor data for irrigation recommendations: revealing the agronomist's tacit knowledge. Precision Agriculture, v. 19, n. 3, p. 421-444, 2018.

HUNT JUNIOR, E. R.; DAUGHTRY, C. S. T. What good are unmanned aircraft systems for agricultural remote sensing and precision agriculture? International Journal of Remote Sensing, v. 39, n. 15/16, p. 5345-5376, 2018.

INSTITUTO BRASILEIRO DE GEOGRAFIA E ESTATÍSTICA (IBGE). Levantamento sistemático da produção agrícola. 2018. Disponível em: https:// www.ibge.gov.br/estatisticas/economicas/agricultura-epecuaria/9117-producao-agricola-municipal-culturastemporarias-e-permanentes.html? $=\& \mathrm{t}=$ resultados. Acesso em: jun. 2020.

JAWAD, H. M.; NORDIN, R.; GHARGHAN, S. K.; JAWAD, A. M.; ISMAIL, M. Energy-efficient wireless sensor networks for precision agriculture: a review. Sensors, v. 17, n. 8, p. 1-45, 2017.

JI'AN, X.; HONGXIN, C.; YUWANG, Y.; WEIXINB, Z.; QIANB, W.; LEIA, X.; DAOKUOB, G.; WENYUB, Z.; YAQIA, K.; BO, H. Detection of waterlogging stress based on hyperspectral images of oilseed rape leaves (Brassica napus L.). Computers and Electronics in Agriculture, v. 159, n. 1, p. 59-68, 2019.

KRISHNAN, P.; SINGH, R.; VERMA, A. P. S.; JOSHI, D. K.; SINGH, S. Changes in seed water status as 
characterized by NMR in developing soybean seed grown under moisture stress conditions. Biochemical and Biophysical Research Communications, v. 444, n. 4, p. 485-490, 2014.

LOCKE, A. M.; ORT, D. R. Leaf hydraulic conductance declines in coordination with photosynthesis, transpiration and leaf water status as soybean leaves age regardless of soil moisture. Journal of Experimental Botany, v. 65, n. 22, p. 6617-6627, 2014.

LOPES, A. S. Manual de fertilidade do solo. São Paulo: ANDA/Potafos, 1989.

LOPES, A. S.; SILVA, M. C.; GUILHERME, L. R. G. Acidez do solo e calagem. São Paulo: ANDA, 1991. (Boletim técnico, 1).

MACHADO, M. L.; PINTO, F. de A. C.; PAULA JUNIOR, T. J. de; QUEIROZ, D. M. de; CERQUEIRA, O. de A. T. White mold detection in common beans through leaf reflectance. Journal of the Brazilian Association of Agricultural Engineering, v. 35, n. 6, p. 1117-1126, 2015.

MARENCO, R. A.; LOPES, N. F. Fisiologia vegetal: fotossíntese, respiração, relações hídricas e nutrição mineral. Viçosa: Ed. UFV, 2009.

MINAS GERAIS. Zoneamento agroclimático do Estado de Minas Gerais. Belo Horizonte: Epamig, 2017.

OLIVEIRA, F. A. de; SFREDO, G. J.; CASTRO, C. de; KLEPKER, D. Fertilidade do solo e nutrição da soja. Londrina: Embrapa Soja, 2007. (Circular técnica, 50).
RUVIARO, C.; DORNELES, J. G. L.; SILVA, A. M.; BEN, C. A. V. Comportamento da soja submetida a diferentes regimes hídricos e viabilidade da irrigação suplementar na região do Vale do Jaguari - RS. Perspectiva, v. 35, n. 131, p. 79-90, 2011.

SIEBERS, M. H.; YENDREK, C. R.; DRAG, D.; LOCKE, A. M.; RIOS ACOSTA, L.; LEAKEY, A. D. B.; AINSWORTH, E. A.; BERNACCHI, C. J.; ORT, D. R. Heat waves imposed during early pod development in soybean (Glycine max) cause significant yield loss despite a rapid recovery from oxidative stress. Global Change Biology, v. 21, n. 8, p. 3114-3125, 2015.

SILVA, R. R. da; RODRIGUES, L. U.; FIDÉLIS, R. R.; FARIA, Á. J. G. de; NASCIMENTO, V. L. Nutritional and morphophysiological responses of soybean to micronutrient fertilization in soil. Communications in Plant Sciences, v. 9, n. 1, p. 93-99, 2019.

TIBI, R.; KOPER, K. D.; PANKOW, K. L.; YOUNG, C. J. Discrimination of anthropogenic events and tectonic earthquakes in Utah using a quadratic discriminant function approach with local distance amplitude ratios. Bulletin of the Seismological Society of America, v. 108, n. 5, p. 2788-2800, 2018.

WIJEWARDANA, C.; REDDY, K. R.; ALSAJRI, F. A.; IRBY, J. T.; KRUTZ, J.; GOLDEN, B. Quantifying soil moisture deficit effects on soybean yield and yield component distribution patterns. Irrigation Science, v. 36, n. 4-5, p. 241-255, 2018. 